\title{
INNOVATIVE ABSORPTION OF THE POLISH ECONOMY AND DIRECTIONS THEIR GROWN
}

\author{
Oleksandr OKSANYCH \\ Kielce University of Technology; oksanycz@tu.kielce.pl, ORCID: 0000-0002-6163-1231
}

\begin{abstract}
Purpose: The purpose of the article is to assess the ability of the Polish economy to absorb innovative products and to analyze the factors on which it depends.

Design/methodology/approach: The methods of critical analysis and synthesis, the method of generalization and logical methods as well as the desk research method were used in the research process.

Practical implications: The article contains the definition and content of the concept of innovative adsorption of participants and beneficiaries of the innovation process as a necessary feature of building a knowledge-based economy. On the basis of reading scientific sources and statistical data, the author presents cause-and-effect relations between the involvement of enterprises and organizations in innovative processes and economic development.

Originality/value: The author presented his own definition of the concept of innovative absorption of the economy and developed a concept of creating innovative absorption in the enterprise. The article is aimed at enterprise managers, decision makers of state institutions and scientists dealing with innovation problems.
\end{abstract}

Keywords: innovative absorption, economic development, enterprise management.

Category of the paper: Research paper.

\section{Introduction}

The beginning of the 21 st century is characterized by a dynamic change of priorities in the use of production factors. The post-industrial economy is transforming into a knowledge-based economy with one of the key features being a high level of innovation. The ability of the economy to generate new ideas, their development and commercialization of products based on these ideas becomes an indispensable condition for competitiveness on the global market. In the conditions of globalization and development of information technologies, costs and risks are increasing, related to innovative activities, the life cycle of innovations is shrinking. On the other hand, the emergence of market-accepted innovations provides the company with 
tangible benefits in the form of increased sales, profits, customer loyalty and Innovations are increasingly affecting economic development. Therefore, interest in innovation on the part of companies is becoming a common phenomenon and is increasingly the subject of scientific research.

Innovations are increasingly affecting economic development. The economy based on the use of innovative products is characterized by a high level of resource use and a growing level of society's living standards. The most developed economies in the world are the most innovative economies.

After the political changes at the turn of the 1980s and 1990s, Poland came across the need not only to build state institutions and management systems on the principles of democracy and market economy, but also to make up for the delay in technological development.

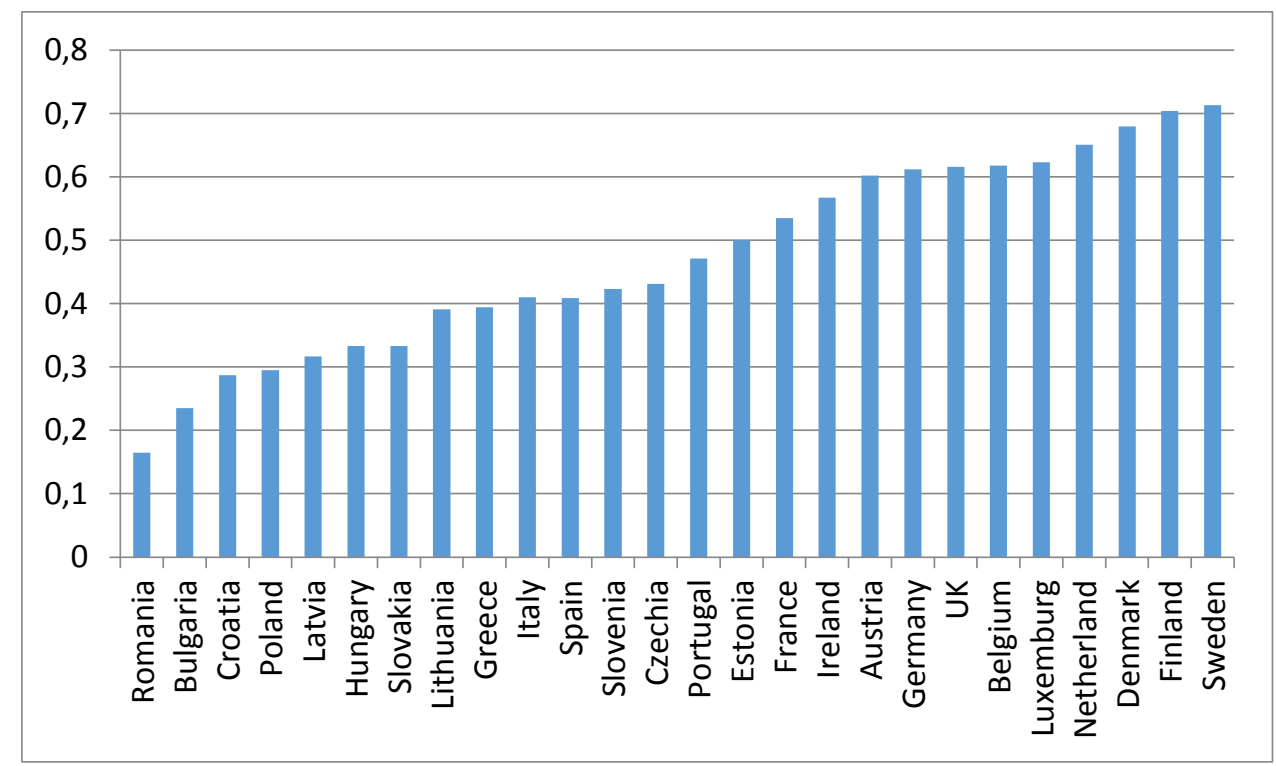

Figure 1. Summary Innovation Index. Source: (European innovation scoreboard, 2019).

The innovation of the economy depends on several factors. In each country, its genesis is a reflection of internal (national) and external (international) political, social and economic processes that conditioned the creation of national innovation systems. The innovativeness of the Polish economy is at a level which, according to the European Innovation Scoreboard methodology, is assessed as moderate (Figure 1). An analysis of the causes that inhibit innovative activity in Poland, quite detailed in numerous domestic and foreign publications.

Poland's accession to the EU allowed to receive support not only in the form of financial resources (European innovation scoreboard, 2019) but also in the form of transfer of innovation. The implementation of European innovative products in Polish enterprises, on the one hand, contributed to their technological modernization, on the other - it caused an slower increase in the innovativeness of the Polish economy compared to EU countries (Rybiński, 2013).

The problem is that innovation depends not only on access to innovation, but on the awareness of their implementation, the belief that innovation-based development has no 
alternative. Creating pro-innovative attitudes in society is a basic condition for qualitative changes in the economy. The result of these changes will be an increase in the innovative absorption of the economy, reflecting the needs in innovation, the desire to introduce changes and to create a knowledge-based economy.

\section{Innovative absorption capacity and its determinants}

The concept of absorbency in economics and management is most commonly used to refer to knowledge. However, knowledge is a multi-faceted concept. In the sphere of innovation, knowledge is interpreted first of all as a source of new ideas and solutions in the field of technology, technique, products, organization and management. However, knowledge also helps to use the results of innovative activities, because knowledge of market behavior of competitors, changes in consumer tastes and preferences, of trends in the development of technological systems, of possible effects of implementing innovative products allows to make rational managerial decisions. This means that knowledge absorptiveness is a decisive factor for the economy's ability to absorb innovative products, and innovative absorptiveness can be defined as the knowledge-based process of transferring innovation into business practice.

Reading scientific publications on the issues raised suggests that the concept of the absorption of knowledge is broader than the concept of the absorption of innovation, which can be interpreted as part of it.

Zahra S. and G. George define absorption capability as a set of organizational routines and processes by which firms acquire, assimilate, transform and exploit knowledge to produce a dynamic organizational capability (Zahra et al., 2002, p. 186).

Xinhua B., Cuiling Y depict the absorption of technology as the whole process of recognizing, identifying, accepting, implementing and spreading technology in an organization, based on the technical and environmental strategy of organizations (Xinhua at al., 2008, p. 338).

The absorption of innovations from the environment and resulting from their diffusion means the process of their acceptance and use by the organization. This process includes five phases: awareness of innovation, interest in innovation, analysis of the possibilities of use, testing, implementation (Leszczyńska, 2011, p. 21).

According to M. Barańska-Fischer, the process of absorbing innovation is reflected in the following stages:

- realizing the need for innovation,

- searching for sources of information on innovation,

- analysis of available information content on innovation,

- shaping attitudes towards innovation,

- deciding on the acceptance of innovation, 
- implementation of the order,

- confirmation of the decision taken while using the innovation,

- collecting information on the effects of using innovation (Barańska-Fischer, 2016, p. 71).

D. Sjodin, D. Frishmmar and S. Thorgren present a process model of how individuals engage in the absorption of new external knowledge, contains three stages: valuing the potential of knowledge, confirming the value of knowledge, supporting the integration of knowledge (Sjodin at al., 2018, p. 372). This knowledge absorption mechanism makes to understand how knowledge creates the need for innovation needs and to start the absorption process.

The conceptual article Martinkenaite I. and K.J. Breunig (Martinkenaite at al., 2016) presents the interaction between the individual and organizational level and explains how the relationship between the individual level and the level of the organizational unit affect the process of knowledge absorption and ensures an increase in innovation.

P. Sun and H. Anderson analyse the individual's role in knowledge acquisition, focus to how new external information leads to organizational-level exploitation through capabilities. They explore the relationship between absorbent skills and organizational learning, and analyze forms of transforming knowledge into creating innovative needs (Sun at al., 2010).

Absorption is a costly learning activity that a firm can employ to integrate and commercialize knowledge and technology that in new from the firm, but not new for the world. For simplicity development of new-to-the-world knowledge can be considered innovation. Innovation shifts a notional technological frontier outward, while absorption moves a firm closer to the frontier. Examples of absorption include: adopting new products and manufacturing processes developed elsewhere, upgrading old products and processes, licensing technology, improving organizational efficiency, achieving quality certification, etc. (Goldberg et al., 2008, p. 2).

Summing up the presented approaches, it is possible to define the absorption of innovations as a knowledge-based process of introducing innovations into business practice, which includes stages of realizing the need for innovation, collecting and analyzing information on innovative products and sources of their acquisition, identifying possible ways of obtaining innovative products and their implementation.

From the position of economy and business management, knowledge allows to understand the processes occurring in society, economy, technology, management, explain the causalconsequential relationship in these processes, creates awareness of changes and inspires the search for ways to make these changes. On the one hand, knowledge contributes to the generation of innovation, on the other - allows to analyze the needs in innovation, assess the sources of their acquisition and find ways to implement them effectively.

The stage of commercialization of innovation is a reflection of how the economy's ability to generate innovative products and the ability to use these products in practice. Innovative absorption capacity of the economy only increases when its innovativeness increases. 
The transfer of innovative products may seem to be a process ensuring the increase of innovation and innovative absorptiveness. However, transferred innovative products do not ensure an increase in competitiveness in international markets due to the fact that, firstly, these products have been implemented in the practice of countries of origin and have been used for some time, secondly, the transferred innovations are available to all market agents, including and for competitors.

Innovative absorptiveness closely related to innovation, because in the context of globalization, innovations are international, and therefore based on the use of comparative advantages and a high level of integration. The high level of innovation of the country means a high level of import and export of high and medium high technology products.

The close relationships between the innovative absorption capacity of the economy and knowledge lead to the conclusion about the role of socio-cultural factors of knowledge acquisition in creating innovative awareness of the society. Education is a key factor in this process. Education is the foundation of our economy. What (and how) we learn in school determines who we become as individuals and our success throughout our lives. It informs how we solve problems, how we work with others, and how we look at the world around us. In today's innovation economy, education becomes even more important for developing the next generation of innovators and creative thinkers (McKinney, 2017).

Knowledge applies to all aspects of the enterprise, creates the culture of the organization and determines the effectiveness of the management system. The repeated interaction between the accumulation of knowledge and the creation of routines to valorise and exploit it eventually leads to the creation of dynamic capabilities that favour the systematic reliance on innovation as a competitive tool (Antonelli, 2012, p. 8).

An organization's capacity for innovation stems from an innovation system: a coherent set of interdependent processes and structures that dictates how the company searches for novel problems and solutions, synthesizes ideas into a business concept and product designs, and selects which projects get funded (Pisano, 2015).

The structure of the economy has a great impact on innovation absorption. This is due to the assumption that a larger share of high and medium high technology production needs the use of more advanced technological systems and their elements, and high qualifications of employees, which forces enterprises to introduce innovations. The higher the effectiveness of competitors in the same industry, the greater the likelihood that each company relies on introducing innovation as a competitive tool and the stronger the sustainability of innovation will be (Aghion, 2005).

However, the improvement of the economic structure as well as the creation of innovative awareness of the society is possible only in the conditions of the efficient functioning of state institutions, ensuring basic rights and freedoms for business. 


\section{Innovative absorption of polish economy}

Awareness of the role of innovation in the development of the economy and increasing its competitiveness conditions the need to measure the level of its innovative absorption. The innovative absorptivity is often identified with the innovativeness of the economy. D.F. Midgley and G.R. Dowling (Midgley et al., 1978) interpret innovation as the tendency to adopt innovations, characterized in three different levels. The actualized innovativeness (the degree to which an individual is relatively earlier in adopting an innovation than other members in its social system), domain-specific innovativeness (the tendency to learn about and adopt innovations in a product category) and innate innovativeness (inner cognitive style of consumers that presents an inherent tendency to try new things or the willingness to change), whereas the abstraction increase from the first to former level. From this point of view, the innovation absorptiveness can be presented by indicators of innovativeness, e.g. SII - summary innovation index, calculated in accordance with the methods of the European Commission (European innovation scoreboard, 2019).

However, innovation should be interpreted as a broader concept than the absorption capacity of innovation. The Oslo Manual defines innovation as the ability of enterprises to create and implement innovations as well as the actual ability to introduce new and modernized products, new or changed technological or organizational and technical processes (Oslo) Absorption of innovation means, above all, the ability to accept, take over and use them, to "draw in" their regardless of their source.

The company "absorbs" this innovative product, which, according to the management, allows to achieve the set goals in the most effective way. The selection criteria are usually costs and level of risk. Innovation transfer occurs when the testing and implementation of own innovative products are more expensive and more risky.

Thus, the measure of innovation absorption can be the amount of funds that are spent on creating your own innovations, as well as funds that have been allocated to the purchase of innovative products from outside.

The amount of expenditure on innovative products, regardless of their origin, in an economy with optimal conditions for their implementation in a given time horizon can be interpreted as the quantitative characteristic of the absorption capacity of the economy. The qualitative aspect of absorption is reflected in the structure of expenditure by types of innovative products and sources of their origin.

Table 1 presents the volume and structure of expenditure on innovative activities in medium and large industrial and service enterprises in Poland. 
Table 1.

The volume and structure of expenditure on innovative activities in medium and large industrial and service enterprises in Poland

\begin{tabular}{|c|c|c|c|c|c|c|c|}
\hline \multirow[t]{4}{*}{ Years } & \multirow[t]{2}{*}{ Total } & \multicolumn{6}{|c|}{ of which } \\
\hline & & R\&D & $\begin{array}{l}\text { acquisition } \\
\text { of external } \\
\text { knowledge }\end{array}$ & $\begin{array}{l}\text { acquisition } \\
\text { of software } \\
\text { activity }\end{array}$ & $\begin{array}{l}\text { capital } \\
\text { expen- } \\
\text { ditures } \\
\text { on fixed } \\
\text { assets }\end{array}$ & $\begin{array}{l}\text { staff } \\
\text { training } \\
\text { connected } \\
\text { with } \\
\text { innovation }\end{array}$ & $\begin{array}{l}\text { marketing } \\
\text { for new } \\
\text { and } \\
\text { signify- } \\
\text { cantly } \\
\text { improved } \\
\text { products }\end{array}$ \\
\hline & \multicolumn{7}{|l|}{ In $\mathrm{mln} \mathrm{zl}$} \\
\hline & \multicolumn{7}{|c|}{ Industrial enterprises } \\
\hline 2011 & 19376,5 & 2617,2 & 257,8 & 428,6 & 15003,2 & 64,8 & 439,4 \\
\hline 2012 & 20293,2 & 3529,7 & 651,2 & 375,7 & 14933,8 & 39,7 & 469,0 \\
\hline 2013 & 19520,7 & 3829,7 & 210,4 & 332,4 & 14321,8 & 127,0 & 370,0 \\
\hline 2014 & 22544,3 & 4415,5 & 220,4 & 387,1 & 16688,9 & 38,7 & 527,6 \\
\hline 2015 & 28920,7 & 4838,3 & 242,8 & 336,1 & 22299,6 & 62,4 & 410,5 \\
\hline \multirow[t]{2}{*}{2016} & 27157,5 & 4988,3 & 157,2 & 423,8 & 20679,8 & 245,0 & 389,9 \\
\hline & \multicolumn{7}{|c|}{ Enterprises in service sector } \\
\hline 2011 & 10317,9 & 1355,3 & \# & 1484,0 & 5658,5 & \# & 462,1 \\
\hline 2012 & 14178,2 & 5795,7 & \# & 1347,1 & 4557,2 & \# & 940,2 \\
\hline 2013 & 9702,3 & 2391,7 & \# & 1640,9 & 4501,1 & 67,8 & 454,8 \\
\hline 2014 & 10790,6 & 2611,1 & 194,4 & 1164,6 & 4813,8 & 50,3 & 1660,5 \\
\hline 2015 & 11855,5 & 3803,2 & 280,6 & 1238,5 & 4660,2 & 140,3 & 965,7 \\
\hline 2016 & 9689,4 & 3973,9 & 493,9 & 939,9 & 2391,8 & 42,7 & 630,2 \\
\hline
\end{tabular}

Source: Author's elaboration based on (sta.gov.pl).

With the data presented in the table 1, that the share in expenditure on innovative activities in medium and large industrial companies includes investment expenditure on remedial measures (over $75 \%$ ), and in services - on R\&D (41\%). There are also visible tendencies to significantly apply R\&D expenditure from $13.1 \%$ in 2011 to $41 \%$ in 2016 . During this period, it is necessary to take into account the dynamic increase in knowledge about external resources in large and medium-sized service companies, while taking into account the scope of imposition in the analysis. Based on the assumption that expenditure on innovation activities can be interpreted as an indicator of innovation absorption, one can state an increase in its structure level by 41\%. In services, this indicator remained stable in 2011-2016.

The economy uses innovations whose structure and scale correspond to its needs. These needs result from the structure of the economy and innovative behavior of enterprises. More technologically advanced industries generate greater demand for innovation due to greater competitive intensity (fig. 2). The production of high technology products means the use of advanced production techniques that ensure the maximum level of efficiency in the use of company resources. "The higher the effectiveness of competitors in the same industry, the greater the likelihood that each company relies on introducing innovation as a competitive tool and the stronger the sustainability of innovation will be" (Aghion, 2005).

Innovative absorption capacity compared to EU countries can be presented by the participation of high technology products in export and import, because innovations significantly change the structure of the economy (Zhang, 2017). 
The low- and medium-low technology sectors that dominate the Polish economy limit the absorption of innovation. The Polish economy remains generally undercapitalized compared with advanced European economies, so closing this gap will mean investing more capital in industry, including for modern machinery and infrastructure (Bogdan at al., 2015, p. 14).

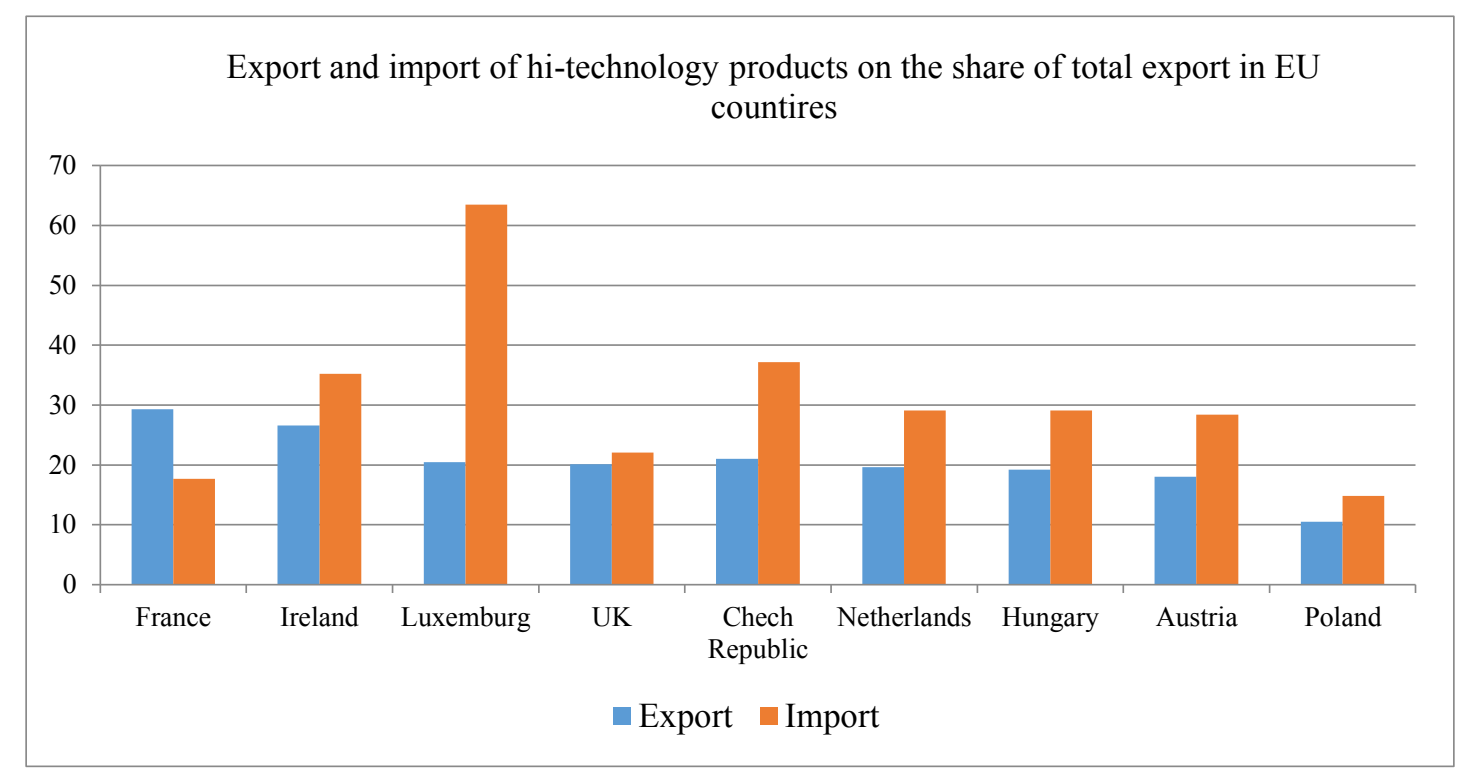

Figure 2. Export and import of hi-technology products on the share of total export and import in selected EU countries. Source: Author's elaboration based on (stat.gov.pl).

Figure 3 presents the structure of net revenue from sales of high, medium-high, mediumlow and low technology products in Poland, which objectively indicates the structure of the economy.

As can be seen from the presented chart, sales of high technology products make up 5.5\% share in net revenues from sale, medium high $-29.3 \%$. This means that in Poland $2 / 3$ of products are produced using middle low or low technology.

Innovative absorption capacity of the economy directly affects sales growth. The effects of innovation are an increase in resource efficiency and the introduction of more attractive products to the consumer. Enterprises perceive innovation primarily through the prism of the possibility of increasing sales, which is a key criterion for absorbing innovation, because $69 \%$ of companies announce sales growth as the most important indicator of innovation (Staack et al., 2017). Each doubling of the cumulative market sales volume due to the use of economies of scale allows to reduce average processing and sales costs by $20-30 \%$ (Becker et al., 1988, p. 335).

The structure of the economy determines also the employment structure. Table 2 presents the structure of net revenues from sale and employment structure by level of technology in Poland in 2016. As can be seen from the data presented, an irrational economic structure means irrational use of labour resources. $28.1 \%$ of employees were employed in high and medium high technology sectors, who generate $34.8 \%$ net revenues from sale, while in the low technology sector the share of employees is $40.9 \%$, then the share of net revenues from sale is 
only $33.4 \%$. On the one hand, this means a low demand for highly qualified employees, which weakens the motivation to acquire relevant knowledge, on the other - a low level of work efficiency in the entire economy.

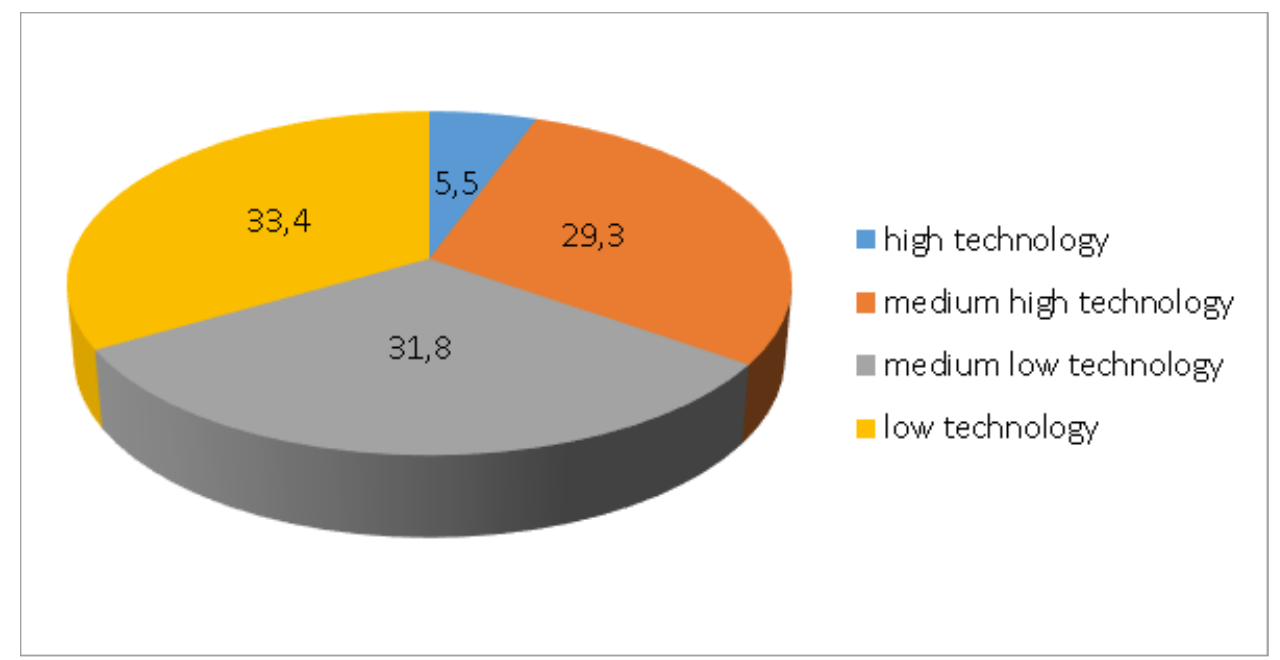

Figure 3. Structure of net revenues from sale of products by level of technology in Poland in 2016. Source: Author's own elaboration based on (stat.gov.pl).

Table 2.

Structure of net sales revenues and structure of employment structure by technology level in Poland in 2016

\begin{tabular}{|l|l|l|}
\hline $\begin{array}{l}\text { Economic sectors by level of } \\
\text { technology in Poland in 2016 }\end{array}$ & Share of employees, \% & Share of net revenues from sale, \% \\
\hline Hi technology & 4,6 & 5,5 \\
\hline Medium Hi Technology & 23,5 & 29,3 \\
\hline Medium Low Technology & 31,0 & 31,8 \\
\hline Low Technology & 40,9 & 33,4 \\
\hline Together & 100 & 100 \\
\hline
\end{tabular}

Source: Author's elaboration by (stat.gov.pl).

The problem of the irrational structure of the economy is related to the economic policy of the state, supporting branches of the economy, which are characterized by outdated technological systems and inefficient management system. First of all, it concerns the mining and energy industries.

Unfortunately, the analysis of the functioning of the basic state institutions indicates a significant deterioration of the investment climate, which adversely affects the innovative absorption capacity of the economy. Business and investors have picked up on the fact that doing business in Poland holds political risk.

To turn things around, Poland must restore the rule of law, privatize the enlarged state sector and undo government monopolies, improve the climate for foreign direct investments, and engage in fiscal reforms, including - most crucially - raising the retirement age (Balcerowicz et al., 2019). 


\section{Creating the absorption of innovation in the enterprise}

Innovative adsorption capacity of the economy is largely determined not only by the macro environment, but also by the activity of economic entities in the search for and implementation of innovative products in the practice of their activities.

According to the results of S. Zahra and G. George, there are four distinct but complementary capabilities that compose a firm's absorptive capacity: acquisition, assimilation, transformation and exploration (Zahra at al., 2002, p. 186).

Awareness of innovation as a competitive factor forces managers to constantly search for ways to achieve the organization's goals based on new ideas and solutions in the field of products, techniques and technologies, organization and marketing. For companies belonging to the group of market leaders or claimants, this awareness allows to bypass the threats resulting from the erroneous belief that the past successes and achievements allow don't pay attention to the progress of competition. For followers and market edge companies, awareness of innovation gives managers the opportunity to recognize early risk symptoms, make the right decisions in advance to implement new solutions, and avoid bankruptcy in this way.

L. Białon and E. Werner define the awareness of innovation "as the perception of information about innovative changes occurring in the surrounding world, their features and mutual relations" and distinguish five stages of its development: zero, basic knowledge about the existence of the problem of innovation, understanding, emergence of need, maturity (Białon et al., 2016, p. 36).

The problem of social awareness of innovation is a historical category and falls within the dimension of intelligent development. In the longer term, the main driving force of development is the dissemination of knowledge (Piketty, 2015, p. 37).

The management system, motivation system and organizational culture are closely related to the creation and use of human capital, which is the basis of the organization's innovation and its investment absorption. However, the creation and effective use of human capital are derived from the external socio-economic environment. This problem has much deeper roots and is closely related to the models for the acquisition of knowledge, qualifications and skills, which are based on the proper functioning of the education and higher education system. The ability to acquire knowledge plays a key role in creating personality with pro-innovative attitudes. This ability depends on the teaching methods and techniques used, based on interest in knowledge. Absorption of knowledge at school or university must be based on non-stressful motivators. Knowledge must be absorbed by learners, but not "pressed" to them under the threat of not obtaining a university certificate or diploma.

Edukacja, mentalność narodowa, wartości społeczne zakładają innowacyjny potencjał osobowości. Jednak wykorzystanie tego potencjału zależy od kultury organizacji, systemu zarządzania wiedzą, systemu motywacji i klimatu psychologicznego w przedsiębiorstwie. 
Od tego zależy rozwój zdolności do pracy w zespole i inicjatywy i potrzebuje stosowania metod i technik, uwzględniających indywidualne cechy, kreujących „esprit de corps” i zachęcające do prezentowania i uzasadnienia własnego punktu widzenia.

Fig. 4 presents a model of innovation adsorption at the company level. The starting point for beginning the search and selection process of the innovation portfolio is the awareness of the need for innovation. It is a process that depends on many interrelated external and internal factors.

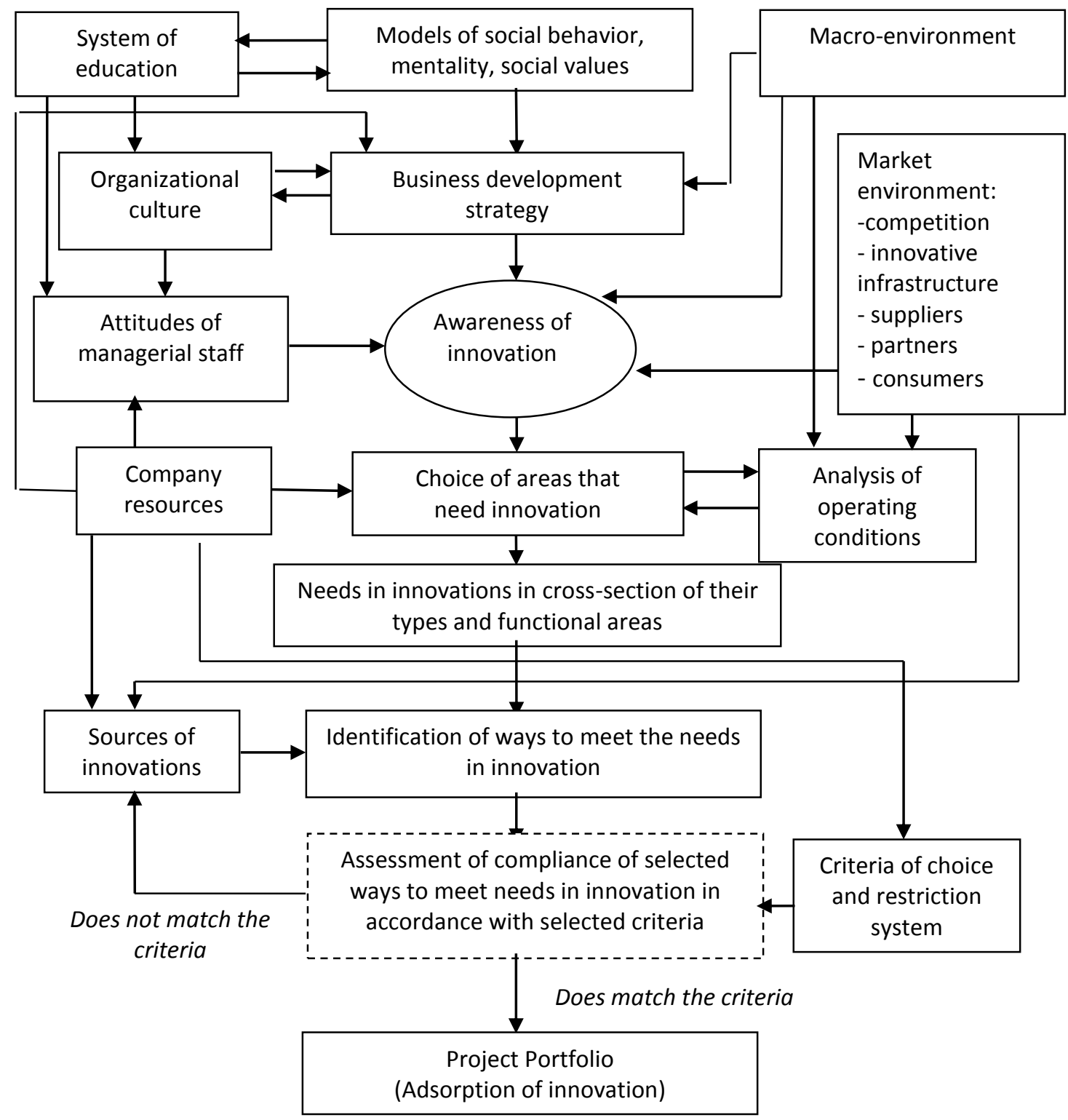

Figure 4. Scheme of creating innovative absorption in enterprise. Source: Author's own elaboration.

The guidelines of the company's development strategy, created on the basis of taking into account the parameters of the external environment and assessment of own resources, define long-term goals. The way these goals are achieved depends on the awareness of the role and importance of innovation. The awareness of innovation results from the attitudes of managerial staff and information from the external environment. Particularly important is information related to innovative activities that are obtained from the market environment. 
Those are:

- data on competitors' products and technology systems;

- information about the innovation market and development trends, conditions for obtaining innovative products, intermediaries, potential partners and clients ect. at the disposal of institutions and the organization of innovative infrastructure;

- information on innovative products and the possibilities of their use from suppliers and partners;

- information about the tastes and preferences of current - potential buyers.

The attitudes of the managerial staff are decisive for realizing the need for innovation. Creative, pro-innovative attitudes of managers, primarily the management, decide to what extent, based on information received from outside about innovation, the company will be involved in innovative activity to achieve the goals set in the development strategy.

The attitudes of managers are determined by the culture of the organization, the level of intellectual capital development, which in turn are a derivative of the effectiveness of the education and higher education system as well as models of behavior and social values.

Awareness of the innovation necessity, assessment of finance and intellectual resources, the results of the analysis of conditions are the base of the choice of options that need innovation. At this stage of the process of advertising innovation, the company defines the needs for innovation in cross-section their types (product, technological, organizational, marketing) and functional areas (product, technological system, marketing, logistics, organization). Then, based on information on sources of innovation, possible solutions that meet the needs in broadly understood products are identified.

The attitudes of managers are determined by the culture of the organization, the level of intellectual capital development, which in turn are a derivative of the effectiveness of the education and higher education system as well as models of behavioral and social values.

Awareness of the innovation necessity, assessment of finance and intellectual resources, the results of the analysis of conditions are the base of the choice of options that need innovation. At this stage of the process of advertising innovation, the company defines the needs for innovation in cross-section their types (product, technological, organizational, marketing) and functional areas (product, technological system, marketing, logistics, organization). Then, based on information on sources of innovation, possible solutions that meet the needs in broadly understood products are identified.

The next stage is the assessment of compliance of selected ways to meet the needs in innovative products, selected criteria and restrictions that are determined by the company's resources. In the case of compliance, the selected innovative solution is included in the portfolio of innovative projects that characterizes the innovative absorption capacity of the enterprise. 
The company's ability to absorb innovation is based on providing three key conditions:

- creating and effective development of knowledge management system;

- continuous improvement of employee motivation and development systems;

- possession of resources needed to implement innovation available.

Knowledge management is important because it provides the necessary elements to solve criticalproblems related to adaptation of the organization, survival and competence to cope with changes in the business environment. Knowledge management must identify the organizational processes that achieve a synergistic combination between the data processing capacity of information technologies and human capacity to create and innovate (Bordeianu, 2015, p. 148). Business practice indicates a very close relationship between company's capacity to collect, analyze and use knowledge and its competitive position. At the end of the 20th century, Alvin Toffler uses that effective company value is related to their strategic ability to acquire, create, distribute and apply knowledge (Toffler, 1996). An effective knowledge management system ensures the creation and effective use of company's human capital, which requires continuous improvement of motivation systems. Knowledge does not ensure its efficient use, if the knowledge carrier will not be interested to use of this knowledge to solve of important tasks for company.

Analysis of scientific publications and survey results leads to the conclusion that the modern effective motivation system is based not so much on material incentives as on personnel policy attractive to employees. In enterprises, non-wage stimuli are more and more often noticed, which not only motivate to work more efficiently, but can also act on retention in a company. Non-financial rewards more effective and faster integrate of employees with the management of the company, create a friendly atmosphere in the workplace, and also shape the image of the company as caring for its own staff (Dziwulski, 2017, p. 49).

To a large extent, the efficiency of creating and using human capital is determined by the personnel recruitment and selection system used in the company. The management of a modern company is faced with the dilemma of choosing between external recruitment and selection and creating staff from a group of company employees. The latter solution seems to be more effective, although it is labour intensive and requires greater involvement of managers in this process.

Survey results indicate that most of the surveyed employers believe that "preparation for work" by university education is not possible: e.g. in the case of IT specialists, technological progress is too fast for lecturers to keep up with the latest news - business in Poland is usually "to forward "in relation to what can be learned at the university. In turn, preparation for work in the PR, accounting or any other department for a larger company would have to take into account many specific procedures and products that are the reality of a particular corporation (Konieczna-Szałamatin, 2012). 
Companies that have achieved significant successes in creating human capital are putting emphasis on providing maximum comfortable psychological conditions to motivate innovative activities. Some companies make special efforts to design a highly motivating role. Toyota encourages play by giving factory workers the opportunity to come up with and test new tools and ideas on the assembly line. W. L. Gore \& Associates gives people free time and resources to develop new ideas. And Southwest Airlines encourages their people to treat each customer interaction as play (McGregor, Doshi, 2015).

\section{Conclusions}

The economy's ability to absorb innovation on the one hand, characterizes the degree of development of intellectual capital of enterprises, on the other - the effectiveness of the state's innovation policy. Greater demand in innovation means not only a higher level of technological development of the economy and its competitiveness on international markets, but also the development of the national innovation system, creating an effective infrastructure for innovation, and $R \& D$ units.

The low level of Poland's innovation threatens to slow down economic development and increase the distance to not only the leading EU economies, but also to countries that only a few years ago were located lower than Poland in terms of GDP per capita.

The review of statistical data and the results of reading scientific publications prove the need for radical changes in Poland's innovation policy. The innovativeness of the Polish economy, which directly affects the absorption of innovations, still remains at a very low level, despite the efforts made by the authorities and some positive changes achieved in the last 16 years, after access to EU. Stagnation in sphere of innovation development threatens to enter a period of economic stagnation. In many scientific publications, the average income trap is mentioned, which is one of the factors of low innovation of the economy.

The increase in the innovativeness of the economy requires, on the one hand, to create friendly conditions for conducting innovative activities, and, on the other, to change the awareness of innovation in society. Innovation starts at school. The pro-innovative attitudes of decision-makers - managers, business owners, politicians, officials, producers of innovative products and consumers depend on how creative, willing and willing to learn knowledge, initiative and ready to cooperate are graduates of universities and colleges. The awareness of the necessity of pro-innovative development is based on culture, mentality and social values. The economy is as innovative as society thinks innovatively.

The challenge for the Polish economy is the development of an effective national research and development system that would generate its own innovative products competitive on international markets and create the foundations of a knowledge-based economy. 


\section{References}

1. Aghion, P., Bloom, N., Blundell, R., Griffith, R. and Howitt, P. (2005). Competition and innovation An inverted U relationship. Quarterly Journal of Economics, 120, 701-28, https://econpapers.repec.org/article/scmecofrm/v_3a4_3ay_3a2015_3ai_3a1_3ap_3a21.htm.

2. Antonelli, C. (2012). Internal and External Factors in Innovation Persistence. Economics of Innovation and New Technology, 22(3), 1-25, p. 8.

3. Balcerowicz, L, Łaszek, A. (2019). Poland economic miracle won't last. Politico. https://www.politico.eu/article/polands-economic-miracle-wont-last/\#, 10.10.2019.

4. Barańska-Fischer, M. (2016). Zarządzanie innowacjami - od powstania idei do komercjalizacji innowacji produktowych. In: M. Barańska-Fischer (ed.), Innowacje w biznesie. Wybrane zagadnienia (p. 71). Monografie Politechniki Łódzkiej.

5. Becker, J. (1988). Marketing - Konception, Grundlagen des strategisches MarketingManagement. Munchen: Vahlen, p. 335.

6. Białoń, L., Werner, E. (2016). The role of university marketing in shaping innovation awareness. Marketing Instytucji Naukowych i Badawczych, Nr 1(19), pp. 36, 37.

7. Bogdan, W., Boniecki, D. Labaye, E., Marciniak, T., Nowacki, M. (2015). Poland 2025: Europe's new growth engine. McKinsey, p. 14.

8. Bordeianu, O.M. (2015). The role of knowledge management and knowledge management strategy within learning organizations. EcoForum, Iss. 1(6), p. 148.

9. Dziwulski, J. (2017). Systemy motywacji pracowników a zarządzanie kapitałem ludzkim organizacji. Zeszyty Naukowe Uniwersytetu przyrodniczo-humanistycznego w Siedlcach, Seria: Administracja i Zarzadzanie, Nr 113, p. 49.

10. European innovation scoreboard 2019: The innovation performance of the EU and its regions is increasing (2019). Europen Comission. https://ec.europa.eu/docsroom/ documents/38781.

11. Fundusze Europejskie, https://www.funduszeeuropejskie.gov.pl/strony/o-funduszach/ zasady-dzialania-funduszy/fundusze-europejskie-w-polsce/, 06.11.2016.

12. Goldberg, I., Bransteller, L., Gottard, J.G., Kuriakose, S. (2008). Globalization and Technology Absorption in Europe and Central Asia. The Role of Trade, FDI, and Crossborder Knowledge Flows. Word Bank Working Paper, Nr 150. Washington: The World Bank, p. 2.

13. Konieczna-Szałamatin, J. (2012). Monitorowanie losów absolwentów uczelni wyższych z wykorzystaniem danych administracyjnych zakładu ubezpieczeń społecznych. Raport z realizacji Modułu 2. Badanie wzajemnych oczekiwań pracodawców, studentów i absolwentów UW. Warszawa. http://produkty.ibe.edu.pl/docs/raporty/285.pdf.

14. Leszczyńska, A. (2011). Absorpcja innowacji ekologicznych w przedsiębiorstwie. Lublin: Wydawnictwo Uniwersytetu Marii Curie-Skłodowskiej, p. 21. 
15. Martinkenaite, I., and Breunig, K.J. (2016). The emergence of absorptive capacity through micro-macro level interactions. Journal of Business Research, 69(2), 700-8.

16. McGregor, L., Doshi, N. (2015). How Company Culture Shapes Employee Motivation. Organizational Culture. Harward Bussines Review, November 25. https://hbr.org/2015/11/ how-company-culture-shapes-employee-motivation.

17. McKinney (2017). Innovation in the Classroom: Why Education Needs to Be More Innovative.

18. https://philmckinney.com/innovation-classroom-education-needs-innovative/.

19. Midgley, D.F., Dowling, G.R. (1978). Innovativeness: The Concept and its Measurement. Journal of Consumer Research, 4, pp. 229-242.

20. Oslo Manual 2018. Guidelines for Collecting, Reporting and Using Data on Innovation. OECD.

21. Piketty, T. (2015). Capital of the 21st century. Warsaw: Wyd. Krytyka Polityczna, p. 37.

22. Pisano, G. (2015). You need an innovation strategy. Harvard Business Review, June. https://hbr.org/2015/06/you-need-an-innovation-strategy.

23. Rybiński, K. (2013). Czy środki unijne niszcza innowacyjność? https://forsal.pl/artykuly/ 680749,rybinski-czy-srodki-unijne-niszcza-innowacyjnosc.html, 14.02.2013.

24. Sjodin, D., Frishmmar, D., Thorgren, S. (2018). How Individuals Engage in the Absorption of New External Knowledge: A Process Model of Absorptive Capacity. Journal of Product Innovation Management Wiley Periodicals, Inc. DOI: 10.1111/jpim.12482, p. 372, 356381.

25. Staack, V., Cole, B. (2017). Reinventing innovation. Five findings to guide strategy through execution. PwC. https://www.pwc.com/us/en/advisory-services/business-innovation/ assets/2017-innovation-benchmark-findings.pdf.

26. Sun, P.Y., and Anderson, M.H. (2010). An examination of the relationship between absorptive capacity and organizational learning, and a proposed integration. International Journal of Management Reviews, 12(2), 130-50.

27. Toffler, A. (1996). Budowa nowej cywilizacji: polityka trzeciej fali. Poznań.

28. Xinhua, B., Cuiling, Y. (2008). Absorptive Capacity of Information Technology and Its Conceptual Model. Tsinghua Science \& Technology, vol. 13, no. 3, p. 338.

29. Zhang, H. (2017). The Innovation-Driven Impact on Economic Structure Transition. The Case of China. International Journal of Management and Economics, 53(4). DOI: 10/1515/ijme-2017-0023.

30. Zahra, S.A., George, G. (2002). Absorptive capacity: a review, reconceptualization, and extension. Academy of Management Review, Vol. 27, No. 2, p. 186, DOI: 10.2307/4134351, https://www.jstor.org/stable/4134351.

31. https://stat.gov.pl/. 